\title{
CLINICAL MANAGEMENT OF A RETREATED MANDIBULAR SECOND MOLAR WITH FIVE ROOT CANALS- REPORT OF A CASE
}

Dennis $^{1}$

${ }^{1}$ Faculty of Dentistry, Universitas Sumatera Utara, Padang Bulan, Medan-20155, Indonesia.

HOW TO CITE THIS ARTICLE: Dennis. Clinical management of a retreated mandibular second molar with five root canals- Report of a case. J. Evolution Med. Dent. Sci. 2017;6(51):3936-3938, DOI: 10.14260/Jemds/2017/851

\section{PRESENTATION OF CASE}

A 38-year-old man was referred to the clinic of Department of Conservative Dentistry, Faculty of Dentistry, University of Sumatera Utara with a chief complaint of discomfort on chewing or percussion and palpation in his left mandibular second molar. Patient presented with a diffuse pain. There was a history of discomfort biting on the tooth. Clinical examination revealed sensitivity to percussion and palpation. There was no response to thermal tests. Electric pulp test also showed negative response of the pulp. Pre-operative radiograph revealed that the tooth has been endodontically treated previously with poor canal obturation (Figure 1). The tooth was planned for re-treatment and the same was explained to the patient. The consent was obtained.

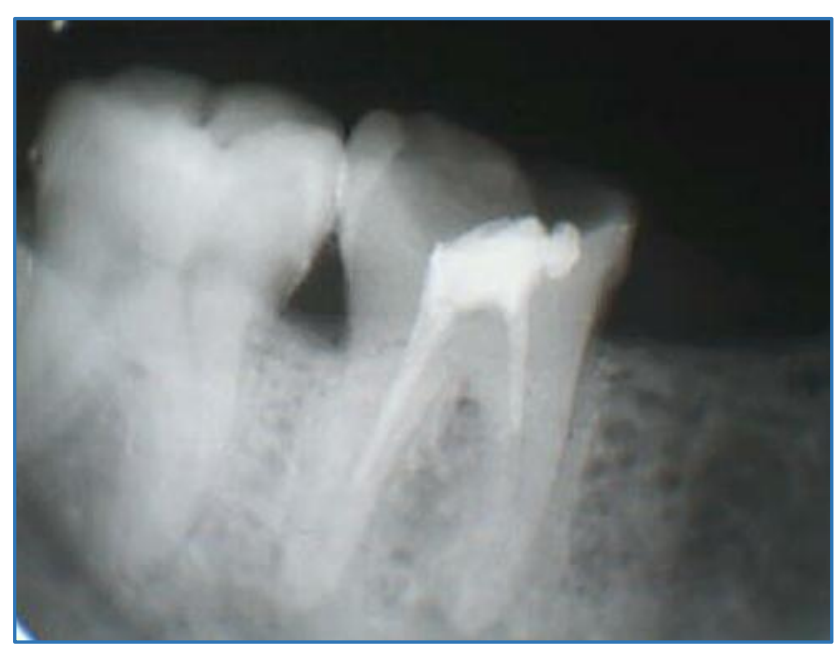

Figure 1. Pre-operative Radiograph

\section{DIFFERENTIAL DIAGNOSIS}

Differential diagnosis of this case is pulp necrosis, apical periodontitis.

\section{CLINICAL DIAGNOSIS}

The clinical diagnosis is symptomatic apical periodontitis due to poor previous endodontic treatment.

Financial or Other, Competing Interest: None.

Submission 10-05-2017, Peer Review 03-06-2017,

Acceptance 09-06-2017, Published 24-06-2017.

Corresponding Author:

Dr. Dennis,

JL. Alumni No. 2, Kampus USU,

Medan-20155,

Indonesia.

E-mail:dennis_dionisius@yahoo.co.uk

DOI: $10.14260 /$ jemds $/ 2017 / 851$

\section{PATHOLOGICAL DISCUSSION}

The infection in the root canal system was not totally eradicated from previous root canal treatment. It was clearly visible from the preoperative periapical radiography. The uncleaned and unfilled root canal system was still infected and the colonisation of mixed microorganism formed bacteria biofilm which elevated their virulence and caused periradicular infection.

\section{DISCUSSION OF MANAGEMENT}

In the first visit, using Gutta-percha solvents (Endosolv E, Septodont Switzerland), the obturated materials in the canals were removed with the use of a deobturation file (Race, Switzerland) (Figure 2).

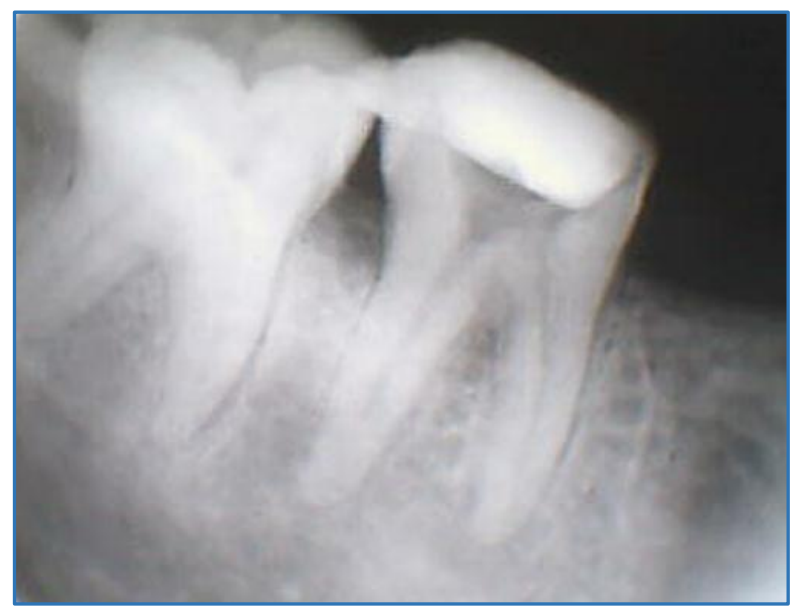

Figure 2. After Removal of Previous Root Canal Filling Material

The negotiation of canals began with no.10 ISO file. On closer inspection with 4.5X magnification prismatic loupes (Zeiss Eyemag Pro S; Carl Zeiss, Italy), the pulp chamber floor was carefully examined for any extra canals. There was a dentin shelf present in between the MB and mesiolingual (ML) canal orifices. This was carefully removed with a number 2 round bur and the floor was examined with endodontic explorer. The third mesial canal orifice was found and located equidistant between MB and ML canal orifices. A \#10 K file (Mani, Japan) was used with EDTA gel (RC Prep) as chelating agent to check the patency of the canal until the size of \#30 K file. The working lengths of all root canals were estimated using an electronic apex locator (Raypex 6, VDW Endodontic Synergy Germany) and then confirmed radiographically with initial files (Figure 3). Cleaning and shaping was done with rotary $M$ two instruments (VDW Endodontic Synergy, Germany) in a crown-down technique. (Figure 4). The irrigation was done with $2.5 \%$ Sodium Hypochlorite, 17\% EDTA solution and 2\% Chlorhexidine. An intracanal dressing with calcium hydroxide was applied for seven days. 


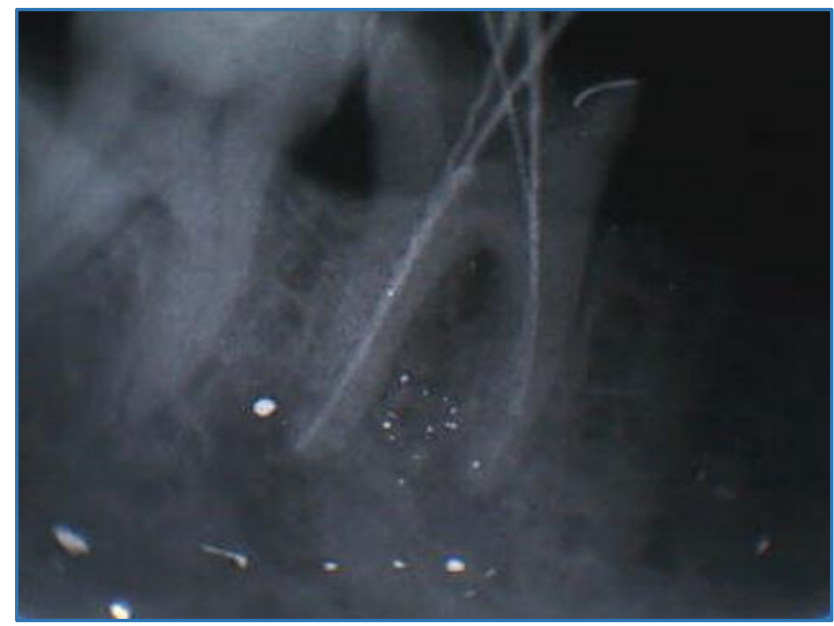

Figure 3. Radiographic of Initial Files

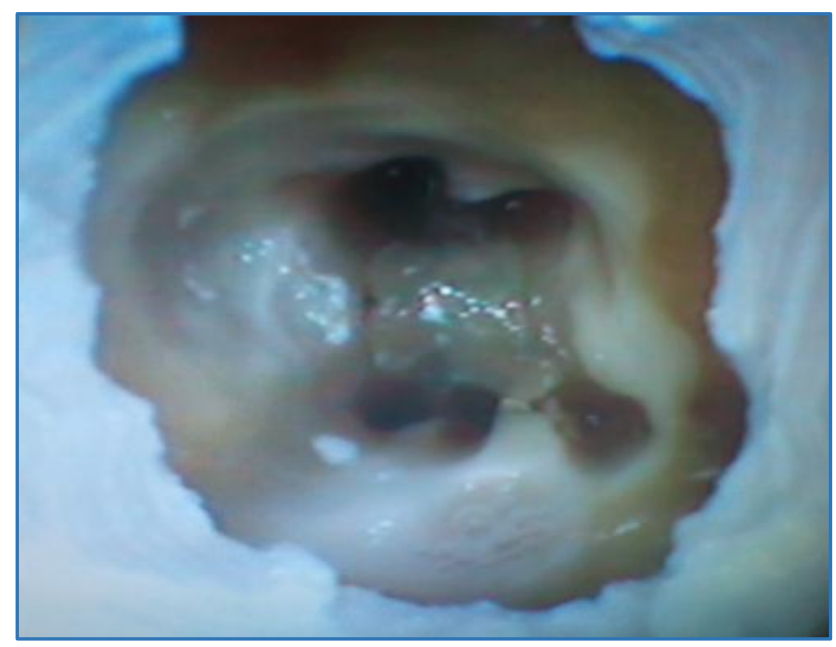

Figure 4. Completion of Cleaning and Shaping

In the second visit, the calcium hydroxide intracanal dressing was removed, the master cone fit was checked and the root canals were dried with absorbing paper points. Root canals were obturated using combination of cold lateral condensation technique and warm compaction technique with MTA based sealer (Fillapex, Angelus Brazil). After obturation, glass ionomer cement was used to seal coronal portion (Figure 5). The tooth required a full coverage restoration to prevent future fracture of the crown.

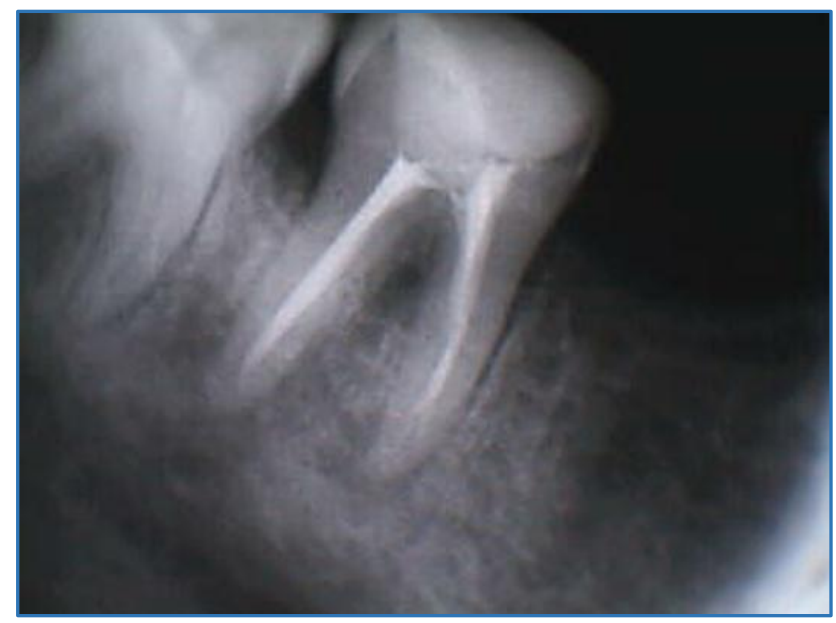

Figure 5. Post-obturation Radiograph
One week later, the final restoration was made with a porcelain-fused-to-metal (PFM) full crown and cemented with Rely X ${ }^{\mathrm{TM}}$ U200 Self-Adhesive Resin Cement (3M ESPE, USA). Occlusion balance was then checked carefully to avoid traumatic occlusion (Figure 6).

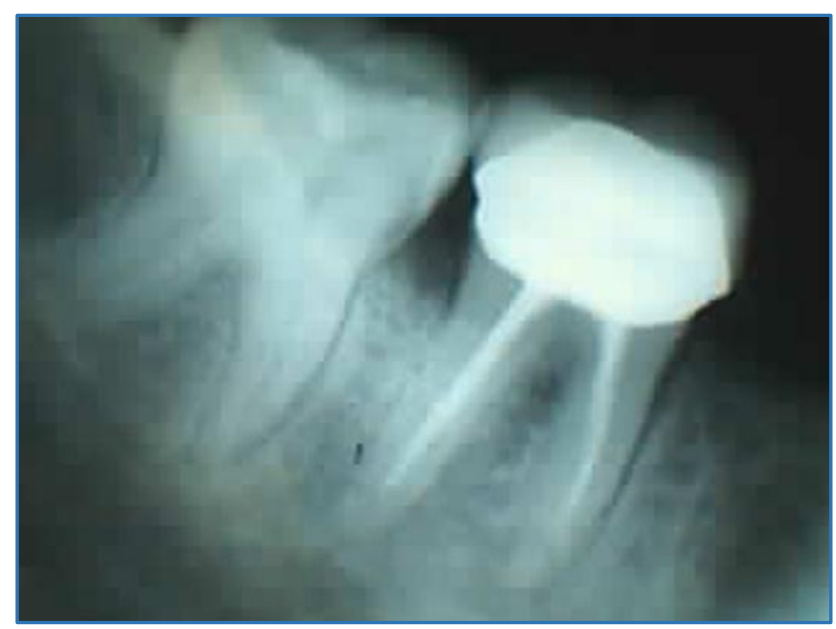

Figure 6. PFM Full Crown as Final Restoration

Before root canal treatment is performed, the clinician should ideally have adequate knowledge of the pulp chamber and internal anatomy of the teeth. All root canals should be accessed, cleaned and shaped to achieve a hermetic fluidtight seal of the entire root canal space. ${ }^{1-5}$ There is an abundant amount of reports related to the anatomic variations of mandibular molars. This should induce the clinician to accurately observe the pulp chamber floor to locate possibly orifices. This will increase the longterm prognosis of endodontic therapy. Therefore, when root canal treatment is to be performed, the clinician should be aware that root canal anatomy may be abnormal.6-10

Middle mesial or multiple canals in the mesial root of mandibular molars have been reported in the literature as having an incidence of $2.07 \%$ up to $13.3 \%$ of the examined case. The canals may be independent throughout their course in the root with an apical opening of their own or they may join either of the two more common main canals. ${ }^{10-12}$

The present report confirms that the third canal in the mesial root of mandibular second molars and to locate it, it must be sought along the line between two mesial canals after de-roofing pulp chamber and of orifice stenosis in this zone that might cover the opening of the canals.

\section{FINAL DIAGNOSIS}

Final diagnosis of the case was chronic apical periodontitis due to poor previous treatment. It was due to infected root canal system and remnant of the necrotic pulp induced the colonisation and formation of bacterial biofilm within the complexity of root canal system which in turn the bacterial invasion reached the periapical tissue to cause apical periodontitis.

\section{REFERENCES}

[1] Cleghorn BM, Goodacre CJ, Christie WH. Morphology of teeth and their root canal system. In: Ingle JI, Backland LK, Baumgarthner JC. eds. Endodontics. $6^{\text {th }}$ edn. Hamilton: BC Decker Inc., 2008:151-210. 
[2] Min KS. Clinical management of a mandibular first molar with multiple mesial canals: a case report. J Contemp Dent Pract 2004;5(3):142-9.

[3] Vertucci FJ. Root canal morphology and its relationship to endodontic procedures. Endod Topics 2005;10(1):3-29.

[4] Sert S, Bayirli GS. Evaluation of the root canal configurations of the mandibular and maxillary permanent teeth by gender in the Turkish population. J Endod 2004;30(6):391-8.

[5] Zhao X, Gong JY. Five root canals in right mandibular first molar: report of one case. Shanghai Kou Qiang Yi Xue 2009;18(2):223-4.

[6] Baugh D, Wallace J. Middle mesial canal of the mandibular first molar: a case report and literature review. J Endod 2004;30(3):185-6.
[7] Peiris HRD, Pitakotuwage TN, Takahashi M, et al. Root canal morphology of mandibular permanent molars at different ages. Int Endod J 2008;41(10):828-35.

[8] Selden HS. The dental-operating microscope and its slow acceptance. J Endod 2002;28(3):206-7.

[9] Yoshioka T, Kobayashi C, Suda H. Detection rate of root canal orifices with a microscope. J Endod 2002;28(6):452-3.

[10] Ruddle C. Non surgical endodontic treatment. In: Cohen S, Burns RC. eds. Pathways of the Pulp. 9th edn. St. Louis: Mosby 2008:875.

[11] Mortman RE, Ahn S. Mandibular first molars with three mesial canals. Gen Dent 2003;51(6):549-51.

[12] Mannocci F, Peru M, Sherriff M, et al. The isthmuses of the mesial oot of mandibular molars: a microcomputed tomographic study. Int Endod J 2005;38(8):558-63. 